No 4(61), 2019, pp. 503-522

https://doi.org/10.12797/Politeja.16.2019.61.27

\author{
Aneta DAWIDOWICZ (D) \\ Maria Curie-Skłodowska University \\ dawidowicz.aneta@gmail.com
}

\title{
NATIONAL EDUCATION \\ AND EDUCATIONAL IDEALS \\ IN THE POLITICAL THOUGHT \\ OF THE NATIONAL PARTY (1928-1939) ${ }^{1}$
}

ABSTRACT In the period of the Second Polish Republic, educational issues constituted a subject matter of interest to Polish political thinkers. Nonetheless, such issues were often perceived differently by the diverse ideological and political factions. According to such political entities, the interwar period was marked by the destabilisation of the previously existing social, political and cultural order, giving rise to a new reality. Visions of creating a "new," "better," more moral and socialised man began to appear in statements of almost all political circles. Such projections, however, entailed the rather disturbing prospect of far-reaching interference in the lives of all citizens, including their privacy. The postulate of changing the individual in order to meet the emerging "higher" objectives, social needs, and "lofty" principles, was put forward. The National Party developed a comprehensive educational programme. The aim of national education was to build a strong nation, and to prepare the society for an independent nation and functioning of the state. The principal categories of the National Party's political thought included work, creation, and action. The condition of Polish society was also thoroughly analysed, with the ideal Pole being depicted as a hard-working, thrifty, conscientious and diligent person, dedicated to the nation and affairs of the state. Active and constructive attitudes were widely promoted, along with social responsibility, readiness

1 This article was drawn up within the framework of the research project entitled "The National Party's Political Thought in 1928-1939," financed from the resources granted by the National Science Centre under decision No. DEC-2013/09/B/HS5/00016. Tekst został opracowany w ramach projektu badawczego "Myśl polityczna Stronnictwa Narodowego (1928-1939)" finansowanego ze środków Narodowego Centrum Nauki na podstawie decyzji numer DEC - 2013/09/B/HS5/00016. 
to make sacrifices, self-determination and subordination to the individuals responsible for the implemented goals. National education was expected to give rise to "a definite Polish type" that would embody the truly Polish character and indigenous values cultivated from generation to generation by the natively Polish population. Its emergence would be possible by imposing adequate discipline and hierarchy.

Key words: political thought, National Party, nationalism

\section{PRELIMINARY REMARKS}

In the period of the Second Polish Republic, educational issues constituted a subject matter of interest to Polish political thinkers. Nonetheless, such issues were often perceived differently by the diverse ideological and political factions. According to such political entities, the interwar period was marked with the destabilisation of the previously-existing social, political and cultural order, giving rise to a new reality. Visions of creating a 'new,' 'better,' more moral and socialised man began to appear in statements disseminated by almost all political circles. Such projections, however, entailed the rather disturbing prospect of far-reaching interference in the lives of all citizens, including their privacy. The postulate of changing the individual in order to meet the emerging 'higher' objectives, social needs and 'lofty' principles, was put forward. ${ }^{2}$

\section{'NATIONAL EDUCATION'}

Modern education formed part of the national pedagogy developed by members of National Democracy (ND). The issue of national education had appeared in ND's political thought since the establishment of this political group. The notion of 'national education' comprised (1) elaborating on the educational process; and (2) determining the objectives of the education process based on the idea of 'nation-oriented education.' Clear-cut views on this issue were expressed by renowned National Democracy theorists, including, in particular, Zygmunt Balicki, Stanisław Głąbiński, Roman Rybarski, Bohdan Wasiutyński, and Stanisław Grabski. Attempts were made to present the essence of the educational process, and to develop a specific role model. A major contribution to the creation of the national education concept was proffered by Zygmunt

2 More information regarding the issue of national education in the Second Polish Republic can be found in: Z. Łempicki, Polskie tradycje wychowawcze [Polish educational traditions], Lviv 1936, passim; L. Zarzecki, Wychowanie narodowe, Studia i szkice [National education, studies and sketches], Warsaw 1929; M. Ziemnowicz, Rodzina a wychowanie państwowe [Family vs. State education], Warsaw 1932; M. Strzelecki, Wizje wychowania spotecznego w polskiej myśli politycznej lat 1918-1939 [Visions of social education in the Polish political thought between 1921 and 1939], Olsztyn 1998; K. Jakubiak, Wychowanie państwowe jako ideologia wychowawcza sanacji [State education as Sanation's educational ideology], Bydgoszcz 1994. 
Balicki ${ }^{3}$. The 'soldier-citizen' model, to which he frequently referred, left a permanent footprint in the work of the national ideologists. Regardless of the many controversies surrounding Balicki's idea of 'national egoism,' his educational thought was widely appreciated among the membership of the Popular National Union and the National Party, with the 'soldier-citizen' model appearing in their numerous publications, this being presented as a variation upon the notion of 'the brave man. ${ }^{4}$ In ND's political thought, the Polish 'self-made man' model was also developed, reflecting the character of the modern economic entrepreneur, whose core objective was to multiply the national economic wealth. ${ }^{5}$

The issues of national education were of significant importance to the National Party (1928-1939). The principles of national education were, as were many other notions, subordinated to the national idea. According to National Party politicians, national education was extremely significant to the nation's development process, as it moulds future generations to consolidate the national identity and strengthen the Polish state. As written by Stanisław Kozicki, The present and future generations are responsible not only for maintaining and strengthening the Polish state, but also (and perhaps more importantly) for making efforts to create a definite Polish type on the popular background. ${ }^{6}$ The postulate of developing 'the Polish type' constituted the leading motive behind deliberations on the essence of national education.

By analysing various accounts of the National Democracy's political thought, a conclusion can be drawn that the ND ideologists expressed keen interest in individuals and their spirituality. The fact that inspiration was drawn from Catholic personalism can be easily observed in the National Party's ideological works. According to national ideologists, people were not perfect beings, and their personality, attitudes and actions

A. Dawidowicz, Zygmunt Balicki, Dziatacz i teoretyk polskiego nacjonalizmu [Zygmunt Balicki - an activist and theorist of Polish nationalism], Kraków 2006, pp. 233-247.

4 Z. Balicki, Zasady wychowania narodowego [The principles of national education] - a speech given at the Polish Pedagogical Congress in Lviv on 1 November 1909], Warsaw 1909, passim; idem, Charaktery a życie polityczne [Characters and political life], Lviv 1914, passim; idem, Egoizm narodowy wobec etyki [National egoism vs. ethics], Warsaw 1902, passim; S. Grabski, Szkota a obywatel państwa i jego rola spoteczna [School and the State's citizens and their role], Lviv 1938, passim; R. Rybarski, Przesztośc gospodarcza Polski [Poland's economic past], Warsaw 1933, passim; S. Głąbiński, Nauka a dobrobyt [Education and well-being], Lviv 1916, passim; B. Wasiutyński, Jak to będzie w wolnej Polsce [How things will be in the free Poland], Warsaw 1918, passim; M. Ryba, Naród a polityka. Myśl spoteczno-polityczna twórców ruchu narodowego w okresie międzywojennym [The nation and politics. The socio-economic thought of the founders of the national movement in the interwar period], Lublin 1999, p. 82.

5 E. Maj, "Droga ponad liberalizmem i socjalizmem w myśli ekonomicznej Narodowej Demokracji" ["A way beyond liberalism and socialism in the economic thought of National Democracy"], Myśl Ludowa, no. 6 (2014), p. 67; idem, "Powstaniec czy polski self-made man. Definiowanie drogi do niepodległości w myśli politycznej Narodowej Demokracji” ["The insurgent or the Polish self-made man. Defining the path to independence in the National Democracy's political thought"], in T. Sikorski, M. Śliwa, A. Wątor (eds.), Piekto i niebo Polaków. Powstania narodowe, bunty i rewolucje. Inspiracje kontynuacje - spory - pamięć [The heaven and hell of Polish people. National uprisings, rebellions and revolutions. Inspirations - continuations - disputes - memory], Kraków 2014, pp. 149-158.

6 S. Kozicki, “Ku źródłom” [“Towards the source”], Myśl Narodowa, 1 October 1933, no. 42, p. 621. 
would require specific corrections. This 'adjustment' process should begin by understanding the unique Polish national character. As written by Karol Stefan Frycz, one of the 'young' journalists, $A$ man is a uniform being and any attempts to heal him should always begin with the spirit.?

\section{THE NATIONAL CHARACTER}

With the prevalence of negative opinions, deliberations on the psyche of the Polish nation were hardly optimistic. Polish people were said to display a range of defects and weaknesses, among which sensitivity, excessive sentimentalism, irritability and passiveness were dominant. Representatives of the national movement made extremely harsh assessments of the Polish nation and did not seek to idealise the national features. Quite to the contrary, they wanted to make Polish people aware of their defects and weaknesses. Karol Stojanowski, a national thinker, did not hesitate to state that the Polish nation suffered from 'a severe moral disease' which, both then and previously, did not allow Poles to take constructive measures, and even rendered any clear-headed assessment of the political reality impossible. This alleged 'disease' was seen as the cause of the loss of independence and the state's structural shortcomings. ${ }^{8}$

In the national press, attempts were made to recreate the image of the individual Pole and his/her national character. This was considered necessary because, as Roman Rybarski advocated, We, Polish people, do not know well our own character. This is hardly surprising because assessing out own features, advantages and disadvantages is usually the most difficult. ${ }^{9}$ It is worth stressing that, by questioning the postulates of racism, the ideologists and journalists who discussed the issues of the national character had no doubts that it constituted a psychological, rather than physical, phenomenon. ${ }^{10}$

Interesting reflections on 'the Polish nation's psyche' were formulated by Ludwik Jaxa-Bykowski, a renowned biologist, pedagogue and anthropologist of the University of Poznań, the vice-chancellor of the underground University of the Western Lands, and a pioneer of Polish experimental pedagogy. Ludwik Jaxa-Bykowski was tied with the National Party and sympathised with the youth group.

While attempting to describe the Polish national character, Jaxa-Bykowski claimed that it was a chivalric nation. Referring to the notion of 'a national soul', he noted that the national character determined the essence of the nation, as well as its well-being, conditions for development, and future. The national soul subconsciously governs our

K.S. Frycz, “Na widowni” ["In the audience”], Myśl Narodow, 12 September 1937, no. 37, p. 582.

$8 \quad$ K. Stojanowski, "Chłop a państwo narodowe" ["Peasants and the nation-state"], in Roman Dmowski. Przyczynki-Przemówienia [Roman Dmowski. Contributions and speeches], Poznań 1936, p. 48; A. Wierzbicki, Naród - państwo w polskiej myśli historycznej dwudziestolecia międzywojennego [The nation - the State in the Polish historical thought in the interwar period], Wrocław 1978, pp. 112-132.

$9 \quad$ R. Rybarski, "O naszym indywidualizmie" ["About our individualism”], Myśl Narodowa, 6 September 1931, no. 43, p. 137.

10 R. Rybarski, Sita i prawo [Power and justice], Warsaw 1936, p. 145. 
thoughts and behaviour, he wrote ${ }^{11}$. According to Jaxa-Bykowski, a national soul (1) determined the potential of a given national community, and (2) constituted a significant national mobilisation factor. It was, therefore, extremely important to the shaping of the national character. The history of the Polish nation clearly proved that it was the national soul that provided the many incentives which had let Poles survive over 100 years of political captivity in order to eventually facilitate laying the foundations for an independent country.

Ludwik Jaxa-Bykowski attempted to describe the Polish national character, recognising both its positive and negative features. In his opinion, the positives included acting with courage, holding an audacious approach to challenges, having dedication, and displaying enthusiasm to work. In turn, the negatives were recklessness, idleness, rebelliousness, and factiousness. In his opinion, when compared to nations displaying higher levels of culture, Poles were distinguished by their "primitive advantages," including cordiality and hospitality. ${ }^{12}$

The national character was viewed as a notion encompassing the spiritual, mental, and moral domains, ${ }^{13}$ while its biological context was rejected. The assessment of Poles, as made by national journalists, was negative. Indeed, some representatives of the $\mathrm{Na}$ tional Party were convinced of the numerous weaknesses and defects evident within Polish society. According to "the fathers of Polish nationalism" and leaders of the Popular National Union, the major drawbacks displayed by the Polish society included recklessness, the inability to make clear-headed assessments of political reality, succumbing to one's own weaknesses, tendencies to waste the legacy of previous generations, idleness, a diminishing sense of individual responsibility for the whole nation, and approval of 'sentimental and lackadaisical patriotism.'

\section{CRITICISM OF THE POLISH NATIONAL CHARACTER}

Passiveness and egocentric indifference to public affairs, deeply rooted in the Polish mentality, were the flaws that raised major concerns among national thinkers. In particular, the criticism of passiveness frequently provided the setting for discussions on educational issues, with this feature being viewed as the principal defect of the Polish nation, strongly influencing the overall characteristics of 'the Polish type.' The sources of "Polish passiveness," so deeply rooted in the Polish national mentality, were sought in the distant pre-partition times. ${ }^{14}$ This stigmatised passiveness took various forms,

11 L. Jaxa-Bykowski, "Nasz charakter narodowy" ["Our national character”], Polityka Narodowa, no. 3 (1938), pp. 244-245.

12 Idem, "Kultura uczuć w wychowaniu" ["The culture of feelings in education”], Myśl Narodowa, 15 August 1937, no. 33, pp. 514-515; idem, "Nasz charakter narodowy" ["Our national character"], Polityka Narodowa, no. 3 (1938), p. 242.

13 R. Rybarski, Sita i prawo..., p. 145.

14 Z. Wardejn, "Dmowski-wychowawca" ["Dmowski - the educator"], Polityka Narodowa, nos. 1-2 (1939), p. 85 . 
including aversion to imposing one's will on other individuals, fears of taking measures to overcome any resistance, the lack of clear-headedness, 'idle' sentimentalism, the lack of active affection for the motherland, fearfulness reflected in all domains of life, and idleness. The depreciated significance of work was considered a specific form of passiveness. Dmowski, who believed that disrespect for work might eventually lead to the collapse of national culture, emphatically cautioned against such danger. He claimed: Civilisation means work. With the decreasing willingness to work, respect for work, and ambitions to create better and higher things, civilisation is doomed to end. ${ }^{15} \mathrm{~A}$ journalist of Polityka Narodowa [National Policy], a magazine published in the late 1930s, expressed similar views, deploring the idleness of Polish people: We are not zealous workers, especially when it comes to independent work and the courageous attainment of a certain position. ${ }^{16}$

It was believed that the numerous weaknesses and faults of the Polish nation were reinforced by unfavourable political, social and cultural phenomena. The National Party, as a group representing traditionalist and Catholic values, expressed fears that such phenomena as secularisation and the disappearance of 'ever-lasting' norms and values would eventually lead to a moral crisis and an even more dangerous distortion of the Polish national character. Concerns were especially raised as regards the triumph of materialistic thought, the disappearance of customary traditionalism, and the expansion of an ideological enemy referred to as the anonymous superpower. ${ }^{17}$ In numerous publications, it was claimed that by straying away from the principles and values based on Catholic teachings, and by abandoning Polish tradition and customs, grounds may be paved for the destructive activities of Jews, Communists and Masons. ${ }^{18}$

It was held that the tradition of the centuries-old rule of the gentry must have left a strong imprint on the character and mentality of the entire Polish society, providing the major cause of the national character's weakness. The dominant position of the gentry was, thus, reflected in the Polish nation's mentality as a whole. It can be inferred, therefore, that, according to the National Party, the gentry were the main cause of the weak character of the Polish nation. With regard to this, the Baroque period was considered the source of negative patterns and the moral stance. ${ }^{19}$ However, it should be noted that a different view was expressed by Karol Stefan Frycz, a talented journalist belonging to the 'youth circle,' who admired that epoch, viewing it as a period marked by the dominance of praiseworthy Catholic-driven values.

15 R. Dmowski, Przewrót [The coup], Warsaw 1934, p. 51.

16 Ibid., p. 87.

17 G. Radomski, "Mit 'mocarstwa anonimowego' w publicystyce obozu narodowego w XX wieku" ["A myth of an anonymous superpower in the National Party's journalistic writing in the $20^{\text {th }}$ century”], in W. Paruch, K. Trembicka (eds.), Świat wokót Rzeczypospolitej. Problematyka zagraniczna w polskiej myśli politycznej w pierwszej potowie XX wieku [The world around the Republic of Poland. Foreign affairs in the Polish political thought in the first half of the 20th century], Lublin 2007, pp. 333-345.

18 K.S. Frycz, "Pozytywizm" ["Positivism"], Myśl Narodowa, 23 September 1934, no. 41, pp. 594-596.

19 J. Zamorski, “Barokowa dusza” [“A Baroque soul”], Myśl Narodowa, 4 August 1929, no. 34, p. 75. 
Along with passiveness, the phenomenon referred to as "the national micro-mania" was also stigmatised. It was described in detail by Jan Rembieliński as a phenomenon whereby some disparaging comment on the nation is always added when an outstanding personality is being praised..$^{20}$ The sense of inferiority typical of Polish people, and the inherently low sense of meaning of the entire Polish nation, were considered the gist of the national micro-mania.

Despite the prevalence of dark shades in the image of the Polish society, national ideologists displayed far-reaching optimism for their national education plans. It was hoped that the condition of the Polish society would be improved by the youngest generation. Roman Dmowski wrote, These generations must create new people who will follow new paths. ${ }^{21}$ Tadeusz Bielecki admitted that while the older generation is characterised with mental, religious, moral and, thus, political anarchy, this is no longer true about the youth circles in which the spiritual and moral order has come to emerge quickly. ${ }^{22}$ The 'youth' themselves positively assessed the direction of social changes, believing in changing the future. Values drawn from the Catholic tradition provided the basis for such optimistic conclusions. The National Party's political thought was thus forwardlooking. Hope for the desired direction of mental transitions within Polish society was reflected in this statement of Wojciech Wasiutyński: We are no longer the individualists from the times of the collapse of the Republic of Poland. We strongly disapprove of the liberal approach expressed through the saying 'Feel free to do as you wish'. We do not believe in the omnipotent system forms. We feel disgust to ideological heresy, and we go back to the medieval image of Poland - a vigorous, disciplined, orthodox and fighting country, looking to the west and willing to conquer. ${ }^{23}$ The already introduced mental changes and social transitions prompted the conclusion that the ideal of an active, self-reliant, hard-working and politically engaged person could actually be brought into effect. ${ }^{24}$

Although the postulated traits of character and personality types were real, their materialisation was expected at some unidentified point in the future. Criticism of the Polish national character was tightly connected with the postulate of its indispensable rehabilitation. National Party journalists repeatedly affirmed that shaping the young Polish nation was still feasible, given especially that, when compared to such old nations as the English or the French, the Polish nation was not mature enough and was in a state of continuous evolution. As written by Jan Zamorski, We are all mindful that our

20 J. Rembieliński, Światek maleńkich ideałów [A little world of tiny ideals], Myśl Narodowa, 1 August 1927, no. 16, p. 281-282; idem, Na widowni [In the audience], Myśl Narodowa [National thought], 24 March 1935, no. 12, p. 186.

21 R. Dmowski, Ludzie potrzebni [The needed people], Myśl Narodowa, 24 December 1933, no. 54, p. 815 .

22 T. Bielecki, $W$ szkole Dmowskiego. Szkice i wspomnienia [At Dmowski's school. Sketches and recollections], London 1968, p. 11.

23 W. Wasiutyński, Najmtodsze pokolenie przez pryzmat "Myśli nowoczesnego Polaka” [The youngest generation as viewed through the prism of "Thoughts of a modern Pole"], 23 August 1931, no. 40, p. 113.

24 W. Zaleski, Ideologia biurokracji [The ideology of bureaucracy], Myśl Narodowa, 23 July 1933, no. 32, p. 461. 
civilisation is young. It is actually the youngest from among the nations that emerged from the western Roman civilisation. ${ }^{25}$

The postulated process of social awareness transition was meant to take place on several planes. The founders of the National Party's political thought thus referred to the words of "the fathers of Polish nationalism." The postulate of modernizing the national character, treated as the prerequisite to rebuilding the power of an independent country, was already made by Roman Dmowski in Myśli nowoczesnego Polaka [Thoughts of a modern Pole] (1903). The feasibility of such reconstruction was compounded by the view, which had consolidated in the National Party's political thought, that the character of the Polish nation was not permanent and unchangeable but was still developing.

Attempts were made, therefore, to reconstruct the nation's psyche. National Democrats advocated thorough and permanent transitions of the national character. Because the nation was viewed as a mental community, it was extremely important to highlight specific role models, as well as to shape the desirable attitudes and behaviours which could strengthen the national structure. Attempts were also made to develop perfect ideological and moral patterns, with appropriate role models being promoted in ideological publications and the diversified press. The educational process was, hence, meant to lead to shaping personalities free from national defects. The widely understood activity, resulting in the desirable changes in both individual people and their surroundings, invariably served as a determinant to all educational ideas.

Tendencies to accentuate the cult of authority, and to emphasise absolute and unquestionable truths, also appeared in the National Party's political thought, along with criticism of phenomena typical of the $20^{\text {th }}$ century such as democracy and liberalism. Such tendencies were reflected in the preferred educational ideal. ${ }^{26}$ The role model of a Catholic Pole, which had emerged back in the $17^{\text {th }}$ century, appeared in the works of the National Party ideologists.

As already mentioned, Roman Dmowski, in his famous book Kościót, naród $i$ panstwo [The Church, the nation and the State] (dated 1927), proved that the issues related to Catholicism could not be perceived separately from those related to the nation. ${ }^{27}$ Young representatives adopted this notion as their political axiom, viewing moral education, consistent with Catholic ethics, as absolutely necessary. ${ }^{28}$ The

25 J. Zamorski, Kurczenie ojczyzny [A diminishing motherland], Myśl Narodowa, 21 July 1929, no. 32, pp. 43-44.

26 S. Kozicki, Likwidacja XIX wieku [19th-century liquidation], "Gazeta Warszawska”, nos. 252-255, 257-259, 261 (1932).

27 R. Dmowski, Kościót, naród i państwo [The Church, the nation and the State], Warsaw 1927, p. 29.

28 K. S. Frycz, „Katolicyzm doktorów” [Catholicism of doctors], “Prosto z Mostu”, 10 November 1935, no. 46, p. 3; S. Rymar, Wyjątkowa chwila [The unusual moment], Myśl Narodowa, 4 July 1937, no. 27, p. 413. W. Wojdyło, Wychowanie jako forma dziatania politycznego w myśli spoteczno-politycznej obozu narodowego w latach 1926-1939 [Education as a form of political action in the socio-political thought of the national movement between 1926 and 1939], in W. Wojdyło (ed.), Wychowanie a polityka. Miedzy wychowaniem narodowym a państwowym [Education and politics. Between national and state education], Toruń 1999, p. 60. 
postulated role model also comprised the 'Catholic Pole' type. As already mentioned, the National Party represented so-called Christian nationalism, expressing views in favour of an axiological system based on Catholic ideas. The concept of Christian nationalism imposed the propagation of education in the Catholic and national spirit. ${ }^{29}$ Respect for Christian principles was recommended, in both the public and private domains. Postulates were, therefore, made in favour of education in the religious spirit, along with obligatory religion lessons at school. ${ }^{30}$ Readers of Podlasiak, a weekly paper published in the Lublin region, were strongly reminded that (...) the principles of Catholic teachings require that all students go to the Church every Sunday and confess their sins at least once a year. ${ }^{31}$ Views were expressed that the Catholic faith provided people with a sense of existence, made them ethically stronger, shaped their 'moral backbone' and determined the optimal direction of their activities. Wojciech Wasiutyński, a leader of the 'youth' circle, had no doubt that (...) national education is hardly possible without the spiritual armour provided by religion (...). ${ }^{32}$ Departure from Catholic teachings entailed a risk of moral collapse and chaos in both the public and private domains.

A significant revision of values can be seen in the National Party's political thought. Whereas the leaders of the early National Democracy (commonly referred to as the Endecja) perceived the preponderance of the national idea as the underlying determinant of national education, the National Party ideologists saw the national education priorities as arising from ethical instructions based on Catholicism.

In the 'youth' circles, a tendency towards an increasingly dogmatic perception of religion was observed. Such a standpoint was represented by Jędrzej Giertych, among others, who wrote in 1929: Who is a Catholic must be fully a Catholic [...]. He or she must accept all the Church's orders, arrangements and dogmas without any reservation and self-elaboration, as well as recognise the authority of the Church hierarchy. ${ }^{33}$ The utilitarian approach to religion began to gradually disappear from the utterances made by the young representatives of National Democracy, whereas Catholicism became an integral element of the national ideology. In 1933, an ND journalist wrote: We, Catholics and Poles, shall not let anyone tear off our Catholic ideas for some alleged national interest, or our national ideas for some alleged Catholic interest. We shall not let anyone persuade us

29 The National Library of the Polish Academy of Learning and the Polish Academy of Sciences, Kraków, Józef Zieliński, file No. 7820, mf. 1448, Pamphlet, 4 Lista Narodowa staje do wyborów aby wywalczyć Narodowi Polskiemu prawo gospodarza we własnym państwie [The $4^{\text {th }}$ National List stands for election to fight for the Polish nation's right to govern its own country], b.p.

30 S. Rymar, Wyjattkowa chwila [The unusual moment], Myśl Narodowa [National thought], 4 July 1937, no. 27, p. 413; R. Dmowski, Oblicza dwudziestego wieku, V. Komunizm [Different faces of the $20^{\text {th }}$ century. V. Communism], "Gazeta Warszawska”, 29 March 1933, no. 96, p. 3.

31 Zetef., Kościót i państwo [The Church and the State], "Podlasiak”, 20 January1932, no. 2, p. 5.

32 W. Wasiutyński, Najmtodsze pokolenie przez pryzmat "Myśli nowoczesnego Polaka” [The youngest generation as viewed through the prism of "Thoughts of a modern Pole"], Mysl Narodowa, 23 August 1931, no. 40, p. 112.

33 J. Giertych, My nowe pokolenie [We-the new generation], Krzeszowice 2000, p. 24. 
that, by breaking our heart into two pieces, we will make any of these ideas stronger. ${ }^{34}$ The worldview based on Catholic teachings influenced the perception of the reality, with the attitude of National Democrats to public life institutions being an accurate example. As it was believed that the Commission of National Education sought to introduce secular education, its activities were criticised. ${ }^{35}$

\section{ROLE MODELS}

Specific role models were sought both in the history and in the current social and political reality. Reference was made to distant historical periods. The fascination with the idea of a 'new Middle Ages,' present in the National Party's political thought, inspired education-related reflections. It was believed that the medieval educational system was adequate, properly shaped the primacy of individual people's objectives and values, and it provided guidelines on fulfilling their duties towards the whole community. ${ }^{36}$

As can be inferred from the National Party's political journalism, the Polish nation could easily find several role models among those of the national movement. Much space in the press was devoted to the most prominent ND politicians, including the 'founding fathers' of Polish nationalism. Their achievements were treated as a significant ideological basis for the widely understood national camp. In light of the journalistic utterances, Zygmunt Balicki was a role model providing a source of positive inspiration for his descendants. A certain ambivalence could, however, be noted in this respect. Namely, while the principle of 'national egoism' was strongly rejected, much appreciation was expressed for the merits he had as the founder of Polish nationalism. This outstanding creator of the structural and ideological bases of National Democracy, who had died in 1916, impressed the "young" generations of national ideologists with a richness of views, extensive actions and diversified interests. It is worth stressing that, apart from his principle of national egoism, which was rather troublesome and questionable, attention was paid to his personal profile, traits of character and moral values that were extremely desirable from the nation's point of view, including disinterestedness, devotion, love for his nation, the courage to disseminate his own views, and teamwork skills. While presenting Balicki's profile and merits to the readers of Myśl Naukowa [National thought], Zygmunt Wasilewski, who had personally known Balicki as a friend and close collaborator, wrote the following words: He was a Renaissance

34 P. Ponisz, Solidarność ideatów [The solidarity of ideals], Myśl Narodowa, 24 December 1933, no. 54, p. 817.

35 J. Giertych, Tragizm losów Polski [The tragic fate of Poland], Pelplin 1936, p. 83; O komunizmie i bezbożnictwie, [About Communism and impiety], Myśl Narodowa, 11 July 1937, no. 28, p. 441.

36 The National Library of the Polish Academy of Learning and the Polish Academy of Sciences, Kraków, Józef Zieliński’s Files, The opening speech, mf. 1448, rkps. no. 7820, p. 104; H. Eysymont, Mówmy o naturze rzeczy [Let us speak about the state of affairs], Myśl Narodowa, 14 June 1936, no. 25, pp. 389-391. 
man. The fact that his courage did not stem from inherent tempers, but from free will, has made him even more valuable for our times. He was a person whom no cross could break. ${ }^{37}$ The memory of the attitude, achievements and ideological works of Jan Ludwik Popławski, who had died in 1908 , was equally positive. ${ }^{38}$

The political history of Poland also offered several valuable and very specific role models, proving that the ideal personality could, in fact, be materialised. By referring to history, it acquired a real form, rather than being confined to writings by national ideologists and journalists. In the search for role models, Piotr Skarga, a Polish Jesuit, theologist and leading figure of the Counter-Reformation, provided a valuable source of inspiration. According to Tadeusz Bielecki, a leading representative of the "youth" circles and the last president of the National Party before World War II, Piotr Skarga, who was a preacher at Sigismund III's court, embodied discipline and obedience. ${ }^{39}$ At this point, it is worth noting that obedience, humility and discipline were considered positive features by the "youth" circles, which, as was frequently stressed in both political writings and the press, should be promoted among the younger generation of Poles. In press articles, it was claimed that the lack of these characteristic features among Polish people had previously led to mistakes and national failures. As stressed by Karol Stefan Frycz, the Polish people were traditionally characterised as displaying disobedience, lawlessness, and a willingness to take ill-conceived, premature and hasty decisions. This had previously led to Poland losing its independence. In a series of articles entitled Na widowni [In the audience], published in Mysl Narodowa, Frycz demanded that the prevalent attitudes be revised. Let us not forget about discipline. While the spirit of mass mobilisation has been our speciality, and has never actually let us down, the discipline aspect has been lacking. It should form part, and be a particularly cherished virtue, of any mass mobilisation, especially in view of its public character. ${ }^{40}$

In line with the idea that a good culture should aim at educating men aspiring to be masters in their own nation, ${ }^{41}$ role models were frequently sought in Poland's cultural achievements, with belles-lettres portraying numerous praiseworthy personalities. Reference was made to the literary image of Bogumił Niechcic - the protagonist of Maria Dąbrowska's novel Noce i dnie [Nights and days]. As written in the press, the protagonist created by Dąbrowska contrasted with the socially alienated individualist, or a type of "homeless man." Niechcic's attitude to life and traits of character such as modesty, simplicity, reliability, diligence, fairness, honesty, straightforwardness, devotion to family, and respect for work were viewed by national journalists as constituting a set of virtues

Z. Wasilewski, Poczatki „Przeglądu Narodowego" [The beginnings of "National review”], "Myśl Narodowa”, 1 August 1937, no. 31, p. 485.

38 E. Maj, Komunikowanie polityczne Narodowej Demokracji 1918-1939 [National Democracy's political communication], Lublin 2010, pp. 27-28.

39 T. Bielecki, Spoteczno-polityczne poglądy Skargi [Skarga's socio-political views], Myśl Narodowa, 27 September 1936, no. 40, p. 627.

40 K.S. Frycz, Na widowni [In the audience], Myśl Narodowa, 30 July 1933, no. 33, p. 517.

${ }_{41}$ Z. Wasilewski, Na widowni [In the audience], Myśl Narodowa, 5 September 1937, no. 36, p. 568. 
that should be praised and followed. ${ }^{42}$ In the search for adequate role models, the principles of romantic messianic philosophy were questioned. While promoting hierarchy, obedience and discipline, the cult of suffering and sacrifice for others was rejected. ${ }^{43}$

In contrast, according to the founders of the National Party's political thought, Stefan Żeromski's works displayed undesirable role models. The literary role model created by the writer, i.e. the 'homeless man,' was an antisocial, introvert and 'typically individualistic' person, devoid of any deeper ties with the society and unfamiliar with higher national ideas. As summarised by Zygmunt Raczkowski, an individualistic man (...) obviously feels no need to establish bonds with the society. Quite to the contrary, he seems proud of his own isolation. ${ }^{44}$ It was believed that the inability to establish deep ties with the nation decreased the value of individuals and did not foster their development. According to Rybarski, a man must be aware that he serves something greater, which goes beyond his private life and effort. In his work for the national idea, he must believe in making effort for the good that will not pass but will remain eternal. ${ }^{45}$ The individualistic attitude, understood as egoistic, antisocial and contrary to the principle of national solidarity, raised strong objections among national journalists, and was widely criticised and discussed in the press. ${ }^{46}$

While searching for the ideal educational model, national journalists referred to the advantages displayed by the peasant class. Views were expressed that the typically Polish character, reflecting truly Polish and national values, should be sought in the plebs. It was further believed that the issue of 'turning peasants into citizens' continued to pose a major problem. According to Zygmunt Wasilewski, the 'Masurian type' would be the desirable educational model to be adopted by Polish schools. The 'Masurian Pole' would stand for hard work, persistence and even fierceness in pursuing his objectives. As written by Wasilewski, he displayed an extremely rich character, a pioneering approach, the ability to perform diversified tasks and formability. ${ }^{47}$ Among the factors strengthening the self, Wasilewski listed historical memory: permanent knowledge of the nation and the state's history. In turn, the afore-mentioned Ludwik JaxaBykowski recommended restitution of middle-class values and ideas, such as hard work, obedience and thrift. ${ }^{48}$ The desirable personality features of nation-state citizens

42 Z. Raczkowski, Naród i jego zwierciadto [The nation and its mirror], Myśl Narodowa, 1 January 1933, No. 1, p. 1; K. L. Koniński, Noce i dni [Nights and days], Myśl Narodowa [National thought] , 22 December 1935, No. 52, pp. 801-804.

43 W. Wasiutyński, Najmtodsze pokolenie przez pryzmat „Myśli nowoczesnego Polaka” [The youngest generation as viewed through the prism of "Thoughts of a modern Pole"], 23 August 1931, no. 40, p. 111.

44 Z. Raczkowski, Naród i jego zwierciadto [The nation and its mirror], Myśl Narodowa, 1 January 1933, no. 1, p. 1.

45 R. Rybarski, O pojmowaniu idei narodowej [Understanding the national idea], "Polityka Narodowa", 1938, nos. 8-9, p. 505.

46 R. Piestrzyński, Absolutyzm a indywidualizm [Absolutism vs. individualism], Myśl Narodowa, $19 \mathrm{Fe}-$ bruary 1933 , no. 10 , p. 115.

47 Z. Wasilewski, Na widowni [In the audience], Myśl Narodowa, 11 May 1930, no. 19, p. 298.

48 L. Jaxa-Bykowski, Nasz charakter narodowy [Our national character], "Polityka Narodowa”, May 1938, no. 3, p. 235. 
were described as follows: obedience, discipline, conscientiousness and devotion shall be required from all individuals towards the nation. Every person shall be subordinated to the ultimate objective - the common good of the nation. ${ }^{49}$ Creative, hard-working and energetic individuals were invariably considered ideal. ${ }^{50}$ It was believed that people with creative potential enabled the nation to maintain its historical continuity. An ideal person should be, therefore, religious, humble and modest, as well as focused primarily on the national, spiritual and 'higher' values. ${ }^{51}$

Young people were encouraged to develop their intellect and fortitude, acquire thorough knowledge, shape positive habits, and, though to a lesser extent, pursue ongoing political activities. The development of such features as persistence, conscientiousness and competence among young people was widely postulated. ${ }^{52}$ Based on the accounts of Tadeusz Bielecki, a representative of the "young" circles and leader of National Party in the late 1930s, Roman Dmowski, the National Democracy leader, was against any premature involvement of young people in political life. He believed that they should first complete a thorough education, and only then engage in political activities. As recollected by Tadeusz Bielecki, the President was against any militarisation of politics and reprimanded us whenever we called him commander [...]. He had grown up in a different historical period and he knew that militarisation would frustrate political effort. He would often say: "I prefer to be an ordinary member of a great ideological and political movement than a commander on a heap of rubbish". ${ }^{3}$ The Camp of Great Poland, based on young people, was seen by Dmowski not as a typically political formation, but as a school of political education.

\section{POLITICAL ROLE MODEL}

Along with developing the ideal educational model, attempts were made to present a political role model. This notion underwent several modifications between 1918 and 1939. In the parliamentary democracy period, the 'politician-educator' and 'politicianteacher' models emerged. ${ }^{54}$ Roman Dmowski, in his famous article Potrzeba nowego

49 Popularne wskazania dla dziatacza narodowego [Common recommendations for national activists], Włocławek 1935, p. 41.

50 Gtosy. Hotd znakomitej dziedziczce [Voices. Paying tribute to an outstanding heiress], Myśl Narodowa, 18 July 1937, no. 29, p. 455; Praca i zabawa [Work and entertainment], "Szczerbiec", 10 January 1930, no. 1, pp. 10-11.

51 R. Dmowski, Ludzie potrzebni [The needed people], Myśl Narodowa, 24 December 1933, no. 54, p. 813; J. Giertych, O wyjście z kryzysu... [Overcoming the crisis], p. 201; W. Wasiutyński, Najmtodsze pokolenie przez pryzmat "Mysli nowoczesnego Polaka” [The youngest generation as viewed through the prism of "Thoughts of a modern Pole"], Myśl Narodowa, 23 August 1931, no. 40, p. 112; Z. Wasilewski, Na widowni [In the audience], Myśl Narodowa, 5 September 1937, no. 36, p. 568.

52 R. Rybarski, Przysztość gospodarcza Polski [Poland's economic future], Warsaw 1933, p. 210.

53 T. Bielecki, W szkole Dmowskiego [At Dmowski's school], London 1968, p. 264.

54 G. Radomski, Polityk-wychowawca. Model dziatacza politycznego w publicystyce Narodowej Demokracji 1918-1939 [A politician-educator. A model of the political activist in the National Democracy's journalistic writing in 1918-1939], in G. Radomski, K. Kalinowska (eds.), Wychowanie a polityka. Cele 
doboru [The need for a new selection], which included a suggestion regarding the purpose of the far-reaching changes in the national camp management, wrote about the need to make a 'new selection' of socially desirable features, and to create the 'Polish type.' We need to place fortitude, and the ability to stay alert and cold-blooded in the most challenging moments, before the gift of the gab and fluency in behind-the-scenes dealings. We need to appreciate responsibility and discipline more than eloquence in fruitless discussions. This selection will not be easy, and it will let only few of the current frontline figures to stay aboard, Dmowski wrote..$^{55} \mathrm{He}$ critically assessed the level of political and moral culture of political players, claiming that we have witnessed the emergence of a politician who is extremely skilful in making deals, compromises and pacts, aimed at deceiving, or even blackmailing, the other party, but who, in difficult circumstances, threatening personal security, prefers to stay quiet as a mouse. ${ }^{56}$

In the National Party period, a 'camper-fighter' model was advocated, embodying discipline, humility and physical strength. As markedly stated in the programme document entitled Idee przewodnie narodowego wychowania [The underlying ideas of national education], a national camp member should display many positive traits of character, among which courage to think and act, conscientiousness, dedication, discipline, persistence, orderliness and political initiative were considered fundamental. ${ }^{57}$ Moreover, national politicians were expected to be honest, and to disapprove of any corruptive and illegal activities. An ideal politician was, therefore, viewed as a comprehensively educated person, placing public service above any particular or group interests, and capable of independently thinking and acting. ${ }^{58} \mathrm{~A}$ person responsible for the national community, as well as ambitious, energetic, active and fully familiar with modern ideas, trends and the latest scientific achievements was considered by the National Party to be a political role model which should be followed by the national youth. It is worth stressing that formal education, erudition and broad intellectual horizons were very much appreciated by national ideologists. Continuous self-education was also of value. Intellectual advantages displayed by politicians were expected to facilitate their functioning in the widely-understood political domain. Ryszard Piestrzyński described a person professionally dealing with politics: Undoubtedly, a politician cannot be an intellectualist with his head in the clouds. He must think and do this clearly. He must not lose contact with the masses, but must work on them. He is not to follow the masses, but the other way round. All this calls for personal energy and liveliness which can be acquired through intellectual

polityczne jako czynnik determinujacy oddziatywanie wychowawcze [Education vs. politics. Political objectives as a factor determining educational impact], Toruń 2004, pp. 33-46.

55 J. Drobnik, Polityka i ludzie [Politics and people], "Awangarda", no. 3 (1928), pp. 55-60; K. Hrabyk, O przemiane w obozie narodowym [Seeking transitions in the national camp], "Trybuna Narodu", no. 5 (1926), p. 1 .

56 R. Dmowski, Pisma, Tom X [Letters. Vol. X], Częstochowa 1939, p. 48.

57 The New Files Archives. A collection of documents of the national camp 1923-1939. Ideological and educational materials, compilations, programmes, file no. 25, Idee przewodnie narodowego wychowania [The underlying ideas of national education], p. 4.

58 S. Niewiadomski, Ideat rycerski [The chivarlic idea], "Awangarda”, nos. 5-6 (1929), p. 98. 
work, not only one's own but also of other intellectualists whose efforts are not limited to politics. ${ }^{59}$ Jerzy Drobnik, displaying significant political aspirations, positively assessed other exceptionally ambitious people. ${ }^{60}$

\section{THE ROLE OF INTELLECTUAL ELITES}

As part of discussions on national education, issues related to the role of the future intellectual elites were touched upon. As such people were considered to be particularly important from the point of view of national interests, attention was paid to both school and academic education. As schools were believed to play an extremely important role in the development of young intellectuals, national ideologists presented their own views on the functioning of the educational system. First of all, it was postulated that the school system be adjusted to the general national education programme, along with ensuring the freedom of education in Poland. ${ }^{61}$ Increased literacy was considered a major aspect of the educational process. ${ }^{62}$ Opinions were also expressed on educational methods and teaching content, attaching much importance to national and state-related matters. Furthermore, manual labour played a significant role in the educational process. It was viewed as having a moral and educative meaning, and as exerting an extremely positive impact on developing the young body. Therefore, any attempts at depreciating the significance of work raised concerns. ${ }^{63}$

Several reflections on educational concepts were disseminated in Myśl Narodowa magazine. In the times of ideological revaluations and struggle against "Grabski's spirit," followed by the school system reform (referred to as the Jędrzejewicz reform), Myśl Narodowa presented strong arguments against the educational ideology propagated by the pro-Piłsudski formation. The magazine even had a permanent column entitled "National education." National journalists, when discussing school-related issues, expressed support for the superintendents and teachers who had been laid off for sympathising with the National Party. In terms of nomenclature, the concept of replacing the nation with the society, which was advocated by theorists of state education, was met with fierce criticism, and so did the idea of replacing a nation member with a citizen. ${ }^{64}$

59 R. Piestrzyński, O zorganizowaniu elity narodowej [Organising the national elite], "Awangarda”, no. 2 (1928), p. 32.

60 J. Drobnik, Polityka i ludzie [Politics and people], “Awangarda”, no. 3 (1928), p. 60.

${ }_{61}$ S. Rymar, Obrona nauki [Defence of education], “Zorza”, 22 January 1933, no. 4, p. 53; S. Rymar, Problemy szkolne [School problems], Myśl Narodowa, 25 July 1937, no. 30, pp. 461-462.

62 The Jagiellonian Library, Stanisław Rymar, Diaries, part III, W Polsce powojennej 1922-1939 [In the post-war Poland 1922-1939], file no. 9797 III, p. 106.

63 Jakie musi być mtode pokolenie? Przemówienie Tadeusza Bieleckiego [How should the youth generation be. A speech by Tadeusz Bielecki], "Awangarda”, nos. 8-10 (1927), p. 4.

64 S. Kilian, Myśl edukacyjna Narodowej Demokracji w latach 1918-1939 [National Democracy's educational thought between 1918 and 1939], Kraków 1997, p. 73. 
Discussions on educational ideology comprised issues referring to the school system transitions, as announced by the Ministry of Religion and Public Enlightenment. The draft amendments published in Gazeta Polska [The Polish Newspaper] in November 1931 were strongly criticized in the national press, with several commentaries being made regarding the organisation of the common education system. Fears were expressed that the re-organisation of education could lead to a sharp decrease in the level of educational services provided in public schools and leave a large number of rural children outside the school system. The new draft act changed the previous organisational structure of common schools, introducing three organisational levels instead of seven: first-, second- and third-level schools. Much interest was also expressed in reforming higher education. The need to change the unilateral humanistic educational profile by introducing technical education had been expressed long before. Attention was paid to the large number of university graduates who could not find a job. The issues of excessive costs borne by the state budget in connection with the higher education system and the decreasing quality of educational services were also highlighted. ${ }^{65}$

Along with their flagship slogans which referred to defending autonomy and reducing tuition fees, the national youth protested against the disproportionately large number of Jews pursuing academic studies, mainly in the field of science, technology and medicine. This phenomenon was connected with tuition rates. It was feared that any further increase in fees would lead to the outflow of young Polish people, who frequently could not afford to pay for their studies, and their replacement by Jewish students residing in Poland as well as coming from the neighbouring countries. ${ }^{66}$

\section{THE ROLE OF FAMILIES IN THE NATIONAL EDUCATION PROCESS}

A significant role in the educational process was played by both formal institutions, such as schools and youth organisations, and non-institutional structures, including families. The family was believed to constitute the domain of the extremely important intergenerational transmission of national values. Such issues as family life, which had previously been confined to the private domain, became full-fledged constituents of political discourse. Family values were enthusiastically advocated by Roman Dmowski, who wrote that the family is a link between an individual and the society, and the society is mainly formed by families, not individuals. ${ }^{67}$ Families were viewed as a guarantee of education of future generations in the Catholic and national spirit. ${ }^{68}$ According to

65 Ibid., pp. 84-85, 94; J. Jastrzębska, O przysztość mtodych [About the youth's future], "Myśl Narodowa", 12 May 1935, no. 19, p. 295.

66 R. Rybarski, Atak rozpaczy [A desperate attack], “Gazeta Warszawska”, 26 February 1933, no. 60, p. 8.

67 R. Dmowski, Pisma, t. X [Letters, Vol. X], Częstochowa 1939, p. 218.

68

The National Library, Warsaw, Social life documents, Collections of irregular printouts, "Głos Ziemi Ostrolęckiej” [The voice of the Ostrotęka Land], a one-off issue devoted to the National Party's work in the Ostrołęka District, Ostrołęka 1936, a speech by Józef Psarski at the Trade and Craft Congress in Ostrołęka on 21 June 1936, p. 11. 
representatives of the national movement, it was the family that laid the main foundation for the nation's existence, being indispensable to human and social development. An ideal family should display strong emotional bonds and a structure relating to OldTestament patriarchalism. According to the party ideologists, family bonds shaped the attitudes of unselfishness and altruism. ${ }^{69}$ While raising the family issue, approval was expressed for traditional moral values. ${ }^{70}$ The traditionalist family model with a hierarchical internal structure was, according to the authors of the National Party's political thought, compliant with the laws of both God and nature. Women were assigned a prominent place in that model. They were expected to protect the national, and traditionally Polish, values and to hand them down to future generations. It was claimed that the traditionalist family model should be legally guaranteed in the Polish nation-state. It was also considered necessary to introduce the adequate codification to ensure the sacramental character of marriage. ${ }^{71}$ While discussing family issues, the National Party ideologists promoted the inseparability of marriage and the idea of having many children, while condemning bachelorhood and families with one child or no children. ${ }^{72}$ The family was believed to pass on the appropriate patterns, behavioural standards and values, and to provide protection against destructive behaviours detrimental to the development and interests of both individuals and the nation as a whole. The National Party declared the need to ensure legally guaranteed family and marriage protection. Care for the development of Polish families was one of the persistent and regularly raised issues in the national press, with harmonious and unbreakable family life being seen as a real value.

\section{CONCLUDING REMARKS}

The National Party developed a comprehensive educational programme. The aim of national education was to build a strong nation, and to prepare the society for an independent nation and functioning of the state. The principal categories of the National Party's political thought included work, creation and action. The condition of the Polish society was also thoroughly analysed, with the ideal Pole being depicted as a hard-working, thrifty, conscientious and diligent person, dedicated to the nation and affairs of the state. Active and constructive attitudes were widely promoted, along with social responsibility, readiness to make sacrifices, self-determination and subordination to the individuals responsible for the implemented goals. National education was expected to give

69 Z. Raczkowski, Ludzie bezdomni [The homeless], Myśl Narodowa, 31 May 1931, no. 26, pp. 338-340.

70 R. Rybarski, O państwie policyjnym [About a surveillance state], Myśl Narodowa, 30 April 1933, no. 20, pp. 273-275.

71 The New Files Archives, Resolutions of the Chief Board of the National Party of 22 November 1931, p. 8.

72 J. Giertych, Po wyborach w Eodzi. Obserwacje i wnioski [The Eódź election. Observations and conclusions], Warsaw 1936, p. 30; R. Rybarski, O państwie policyjnym [About a surveillance state], Myśl Narodowa, 30 April 1933, no. 20, p. 274. 
rise to "a definite Polish type" that would embody the truly Polish character and indigenous values cultivated from generation to generation by the native Polish population. Its emergence would be made possible by imposing adequate discipline and hierarchy.

\section{BIBLIOGRAPHY}

Balicki Z., Charaktery a życie polityczne, Lviv 1914.

Balicki Z., Egoizm narodowy wobec etyki, Warsaw 1902.

Balicki Z., Zasady wychowania narodowego, Warsaw 1909.

Bielecki T., "Społeczno-polityczne poglądy Skargi", Myśl Narodowa, 27 September 1936, no. 40.

Bielecki T., $W$ szkole Dmowskiego, London 1968.

Bielecki T., W szkole Dmowskiego. Szkice i wspomnienia, London 1968.

Dawidowicz A., Zygmunt Balicki, Dziatacz i teoretyk polskiego nacjonalizmu, Kraków 2006.

Dmowski R., Kościót, naród ipañstwo, Warsaw 1927.

Dmowski R., Ludzie potrzebni, Myśl Narodowa, 24 December 1933, no. 54.

Dmowski R., "Oblicza dwudziestego wieku, V. Komunizm", Gazeta Warszawska, 29 March 1933, no. 96.

Dmowski R., Pisma, t. X [Letters, Vol. X], Częstochowa 1939.

Dmowski R., Przewrót, Warsaw 1934.

Drobnik J., "Polityka i ludzie", Awangarda, no. 3 (1928).

Eysymont H., "Mówmy o naturze rzeczy", Myśl Narodowa, 14 June 1936, no. 25.

Frycz K. S., "Na widowni”, Myśl Narodowa, 30 July 1933, no. 33.

Frycz K. S., "Na widowni”, Myśl Narodowa, 12 September 1937, no. 37.

Frycz K. S., "Pozytywizm”, Myśl Narodowa, 23 September 1934, no. 41.

Frycz K.S., "Katolicyzm doktorów”, Prosto z Mostu, 10 November 1935, no. 46.

Giertych J., My nowe pokolenie, Krzeszowice 2000.

Giertych J., Po wyborach w Eodzi. Obserwacje i wnioski, Warsaw 1936.

Giertych J., Tragizm losów Polski, Pelplin 1936.

Głąbiński S., Nauka a dobrobyt, Lviv 1916.

“Głosy. Hołd znakomitej dziedziczce”, Myśl Narodowa, 18 July 1937, no. 29.

Grabski S., Szkota a obywatel państwa i jego rola spoteczna, Lviv 1938.

Hrabyk K., "O przemianę w obozie narodowym", Trybuna Narodu, 1926, no. 5.

"Jakie musi być młode pokolenie? Przemówienie Tadeusza Bieleckiego", Awangarda, nos 8-10 (1927).

Jakubiak K., Wychowanie państwowe jako ideologia wychowawcza sanacji, Bydgoszcz 1994.

Jastrzębska J., “O przyszłość młodych”, Myśl Narodowa, 12 May 1935, no. 19.

Jaxa-Bykowski L., "Kultura uczuć w wychowaniu”, Myśl Narodowa, 15 August 1937, no. 33.

Jaxa-Bykowski L., "Nasz charakter narodowy", Polityka Narodowa, 1938, no. 3.

Kilian S., Myśl edukacyjna Narodowej Demokracji w latach 1918-1939, Kraków 1997.

Koniński K.L., "Noce i dni", Myśl Narodowa, 22 December 1935, no. 52.

Kozicki S., "Ku źródłom”, Myśl Narodowa, 1 October 1933, no. 42.

Kozicki S., "Likwidacja XIX wieku”, Gazeta Warszawska, 1932. 
Łempicki Z., Polskie tradycje wychowawcze, Lviv 1936,

Maj E., "Droga ponad liberalizmem i socjalizmem w myśli ekonomicznej Narodowej Demokracji”, Myśl Ludowa, no. 6 (2014).

Maj E., Komunikowanie polityczne Narodowej Demokracji 1918-1939, Lublin 2010.

Maj E., "Powstaniec czy polski self-made man. Definiowanie drogi do niepodległości w myśli politycznej Narodowej Demokracji”, in T. Sikorski, M. Śliwa, A. Wątor (eds.), „Piekto i niebo Polaków." Powstania narodowe, bunty i rewolucje. Inspiracje - kontynuacje - spory - pamięć, Kraków 2014.

New Files Archives, Resolutions of the Chief Board of the National Party of 22 November 1931.

Niewiadomski S., "Ideał rycerski", Awangarda, nos 5-6 (1929).

"O komunizmie i bezbożnictwie”, Myśl Narodowa, 11 July 1937, no. 28.

Piestrzyński R., "Absolutyzm a indywidualizm”, Myśl Narodowa, 19 February 1933, no. 10.

Piestrzyński R., "O zorganizowaniu elity narodowej”, Awangarda, no. 2 (1928).

Ponisz P., "Solidarność ideałów”, Myśl Narodowa, 24 December 1933, no. 54.

Popularne wskazania dla dziatacza narodowego, Włocławek 1935.

"Praca i zabawa", Szczerbiec, 10 January 1930, no. 1.

Raczkowski Z., "Ludzie bezdomni”, Myśl Narodowa, 31 May 1931, no. 26.

Raczkowski Z., "Naród i jego zwierciadło", Myśl Narodowa, 1 January 1933, no. 1.

Radomski G., "Mit „mocarstwa anonimowego” w publicystyce obozu narodowego w XX wieku", in W. Paruch, K. Trembicka (eds.), Świat wokół Rzeczypospolitej. Problematyka zagraniczna w polskiej myśli politycznej w pierwszej połowie XX wieku, Lublin 2007.

Radomski G., "Polityk-wychowawca. Model działacza politycznego w publicystyce Narodowej Demokracji 1918-1939", in G. Radomski, K. Kalinowska (eds.), Wychowanie a polityka. Cele polityczne jako czynnik determinujacy oddziatywanie wychowawcze, Toruń 2004.

Rembieliński J., “Na widowni”, Myśl Narodowa, 24 March 1935, no. 12.

Rembieliński J., "Światek maleńkich ideatów", Myśl Narodowa, 1 August 1927, no. 16

Ryba M., Naród a polityka. Myśl spoteczno-polityczna twórców ruchu narodowego w okresie międzywojennym, Lublin 1999.

Rybarski R., “Atak rozpaczy”, Gazeta Warszawska, 26 February 1933, no. 60.

Rybarski R., “O naszym indywidualizmie”, Myśl Narodowa, 6 September 1931, no. 43.

Rybarski R., “O państwie policyjnym”, Myśl Narodowa , 30 April 1933, no. 20, pp. 273-275.

Rybarski R., "O pojmowaniu idei narodowej”, Polityka Narodowa, nos. 8-9 (1938).

Rybarski R., Przysztość gospodarcza Polski, Warsaw 1933.

Rybarski R., Sita i prawo, Warsaw 1936.

Rymar S., "Obrona nauki", Zorza, 22 January 1933, no. 4.

Rymar S., "Problemy szkolne”, Myśl Narodowa, 25 July 1937, no. 30.

Rymar S., "Wyjątkowa chwila", Myśl Narodowa, 4 July 1937, no. 27.

Stojanowski K., "Chłop a państwo narodowe", in Roman Dmowski. Przyczynki-Przemówienia, Poznań 1936.

Strzelecki M., Wizje wychowania spotecznego w polskiej myśli politycznej lat 1918-1939, Olsztyn 1998.

The Jagiellonian Library, Stanisław Rymar, Diaries, part III, W Polsce powojennej 1922-1939, file No. 9797 III. 
The National Library of the Polish Academy of Learning and the Polish Academy of Sciences, Kraków, Józef Zieliński, file No. 7820, mf. 1448, Pamphlet, 4 Lista Narodowa staje do wyborów aby wywalczyć Narodowi Polskiemu prawo gospodarza we własnym państwie.

The National Library, Warsaw, Social life documents, Collections of irregular printouts, "Głos Ziemi Ostrołęckiej”, a one-off issue devoted to the National Party's work in the Ostrołęka District, Ostrołęka 1936, a speech by Józef Psarski at the Trade and Craft Congress in Ostrołęka on 21 June 1936.

The New Files Archives. A collection of documents of the national camp 1923-1939. Ideological and educational materials, compilations, programmes, file no. 25, Idee przewodnie narodowego wychowania.

Wardejn Z., "Dmowski-wychowawca”, Polityka Narodowa, nos. 1-2 (1939).

Wasilewski Z., "Na widowni”, Myśl Narodowa, 11 May 1930, no. 19.

Wasilewski Z., "Na widowni”, Myśl Narodowa, 5 September 1937, no. 36.

Wasilewski Z., "Początki Przeglądu Narodowego”, Myśl Narodowa, 1 August 1937, no. 31.

Wasiutyński B., Jak to będzie w wolnej Polsc, Warsaw 1918,

Wasiutyński W., Najmtodsze pokolenie przez pryzmat „Myśli nowoczesnego Polaka”, 23 August 1931, no. 40.

Wierzbicki A., Naród - państwo w polskiej myśli historycznej dwudziestolecia międzywojennego, Wrocław 1978.

Wojdyło W., Wychowanie jako forma dziatania politycznego w myśli spoteczno-politycznej obozu narodowego w latach 1926-1939, in W. Wojdyło (ed.), Wychowanie a polityka. Między wychowaniem narodowym a państwowym, Torun 1999.

Zaleski W., “Ideologia biurokracji”, Myśl Narodowa, 23 July 1933, no. 32.

Zamorski J., "Barokowa dusza”, Myśl Narodowa, 4 August 1929, no. 34.

Zamorski J., “Kurczenie ojczyzny”, Myśl Narodowa, 21 July 1929, no. 32.

Zarzecki L., Wychowanie narodowe, Studia i szkice, Warsaw 1929.

Zetef., “Kościół i państwo”, Podlasiak, 20 January1932, no. 2.

Ziemnowicz M., Rodzina a wychowanie państwowe, Warsaw 1932.

Aneta DAWIDOWICZ - holder of a Ph.D. hab. degree in social sciences, specialising in political sciences; holder of a Ph.D. degree in the humanities, in the field of political sciences; lecturer at the Institute of Political Thought at the Department of Political Sciences at Maria Curie-Skłodowska University in Lublin. Her scientific interests revolve around Polish political thought, biographical writing, the history of the press, political journalistic writing and political communication. She has authored and co-authored several books and scientific articles. The most important include the following monographs: Zygmunt Balicki (1858-1916). Dziatacz i teoretyk polskiego nacjonalizmu [Zygmunt Balicki (1858-1916). A Polish Nationalism activist and theorist], NOMOS Scientific Publishing Press, Kraków 2006, p. 302; Stronnictwo Narodowe 1928-1939. Wspólnota ideatu czy alternacja koncepcji [An ideal community or a concept alternati], Publishing Press of Maria Curie-Skłodowska University in Lublin, Lublin 2017, pp. 409. 